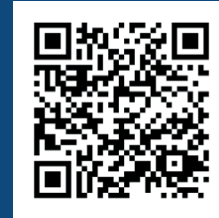

Keywords:

Physical properties of soil Leucaena leucocephala Degraded areas

Historic:

Received 27/1 //2017 Accepted 02/04/2018

Correspondence: kellytonello@yahoo.com
Marcelle Teodoro Lima', Admilson Írio Ribeiro², Herly Carlos Teixeira Dias ${ }^{3}$, Alexandra Guidelli Rosa', Gustavo Trevizan Pires', Kelly Cristina Tonello'+

\section{THE DYNAMICS OF THE SUBSTRATE RECOVERY OF WASTE DUMPS IN CALCARY MINING UNDER NATURAL REGENERATION}

LIMA, M. T.; RIBEIRO, A. I.; DIAS, H. C. T.; BESSI, D.; TONELLO, K. C.; The dynamics of the substrate recovery of waste dumps in calcary mining under natural regeneration. CERNE, v. 24, n. I, p. 18-26, 2018.

\section{HIGHLIGHTS}

Evaluate the dynamics of the physical and chemical recovery of the substrates of waste dumps of different ages undergoing natural regeneration, in a calcary mining.

Characterization of the vegetation, vegetation and physical and chemical cover of the substrates of the abandoned waste dumps since 1994 and 2013 and the soil of a native forest fragment adjacent to the mining was carried out.

The soil cover rate with herbaceous, grassy, regenerating and litter of the sterile stacks are similar to the native forest fragment.

The same was observed for the physical characterization of soil resistance to penetration, soil moisture content and relative light index.

\section{ABSTRACT}

This study aimed to evaluate the dynamics of the physical and chemical recovery of the substrates of waste dumps of different ages undergoing natural regeneration, in a calcary mining in Salto de Pirapora - SP, Brazil. Characterization of the vegetation, vegetation and physical and chemical cover of the substrates of the abandoned waste dumps since 1994 and 2013 and the soil of a native forest fragment adjacent to the mining was carried out. Twelve plots of $10 \times 10 \mathrm{~m}$ were allocated in each environment. It was verified that the soil cover rate with herbaceous, grassy, regenerating and litter of the sterile stacks are similar to the native forest fragment. The same was observed for the physical characterization of soil resistance to penetration, soil moisture content and relative light index. For the chemical characteristics, in all areas sampled there is aluminum deficiency which, consequently, presented low potential acidity and alkaline $\mathrm{pH}$. The CEC of the substrates of the waste dumps presented values similar to the CEC of the native forest fragment, with abundance in some essential nutrients, indicating the possibility of vegetation development in the sterile stacks and the contribution of the natural regeneration to the substrates. Thus, the plant-soil relationship via natural regeneration in the sterile piles contributed to the improvement of the edaphic quality of the substrates over time, being a potential form of recovery in calcary mining. Thereby, the Fabaceae predominated on the waste dumps, especially Leucaena leucocephala, which, despite being an exotic species, is relevant for the current recovery stage of the substrates.
' Federal University of São Carlos, Sorocaba, São Paulo, Brazil

2 São Paulo State University - Sorocaba, São Paulo, Brazil,

${ }^{3}$ Federal University of Viçosa, Viçosa, Minas Gerais, Brazil 


\section{INTRODUCTION}

Exploitation of raw material for civil construction (sand, gravel, clay, limestone, grit, and others) exposes material of diverse composition to the surface, such exposed material being generically called substrate. Substrates exposed by mining activity have physical, chemical, and biological attributes that differ from the ones of soil, which in turn has profile layers and adequate features for growth and development of plants and other organisms (Goedert; Corrêa, 2004).

For Almeida and Sánchez (2015), the restoration of native plant communities is one of the most used ways to recover degraded areas by mining, which creates a new use of the soil with a view to environmental conservation. In fact, the presence of vegetation in the environment improves the physical and chemical characteristics of the soil, while the soil itself concomitantly contributes to vegetation development, which strengthens the relationship between plant and soil.

In the case of calcary mining, the substrate of this activity is disposed in waste dumps, with low levels of nutrients and organic matter, which hinders the development of plants. Thus, specific strategies are necessary for the success of revegetation in such areas, in order to create more favorable soil conditions for the growth and sustentation of vegetation (Corrêa; Bento, 2010). For this reason, it is important to monitor the status of the substrate as a complement to the assessment of vegetation.

The process of substrate recovery as a means to enable plant growth has been shown to be quite slow. However, according to Almeida and Sánchez (2015), monitoring such recovery by measuring substrate functional attributes may provide data that indicate trends of the recovery process, especially when these data are compared with ones of sites without mining interference or even of areas still having remnants of native vegetation, which are taken as reference sites.

Nevertheless, studies addressing areas degraded by calcary mining are still rare. Studies involving a careful analysis of the arboreal component of the vegetation that stablished naturally on areas having mine waste dumps and its relationship with plant cover and with physical and chemical features of substrates, taking into consideration the direct relationship existing between substrate quality and vegetation development, are virtually inexistent. The forest fragment, as well as vegetation density, has an important role in soil, physical, chemical and hydrological restructuring, and may influence the soil moisture distribution and the dynamics of natural regeneration (Honda et al., 2015).
Faced with the difficulty of recovering the soil in the mining process, this study aimed to evaluate the physical and chemical condition of the substrates from different-aged mine waste dumps undergoing natural regeneration and correlate them with a forest environment at an advanced successional stage. In this way, this study seeks to contribute to the development of recovery strategies in the revegetation of mining waste dumps.

\section{MATERIAL AND METHODS}

The study was conducted in the facility of a limestone mining company located at Salto de Pirapora municipality, São Paulo state, southeastern Brazil. The company exploited limestone for production of agricultural inputs and aggregates for building material. The mining facility extends over an area of $26,657.88$ ha, being located between longitudes 47 31 '52.12"

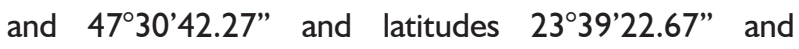
$23^{\circ} 38^{\prime 2} 28.89$ ". According to IBGE (20I2), the study area is located in an ecotone. Vegetation is originally composed of a Seasonal Semideciduous Forest of the Atlantic Forest domain, with zones of contact with plant formations from the Cerrado domain. Climate in the region is type Cwa according to Köppen's classification, i.e. high-altitude tropical climate with rainy summers and dry winters. Temperature of the hottest month averages above $22^{\circ} \mathrm{C}$ (Alvarez et al., 20l3).

The mining company has in its area waste dumps that are abandoned since $20 \mathrm{I} 3$ (Area I) and I 994 (Area II), both of which have been undergoing natural regeneration (Figure $\mathrm{I} a$ and $\mathrm{Ib}$ ). In this environments, the vegetation was structurally characterized, as well the physical and chemical characterization of the substrates. This results was compared to a reference site having a native forest fragment (NFF) adjacent to the mining pit (Figure Ic). We adopted the permanent plot method, with 12 plots of 10 $\times 10 \mathrm{~m}$ in each site, which were grouped in three points with a $10-\mathrm{m}$ interspacing, totalizing a $1200-\mathrm{m}^{2}$ sampling area in each site. Collections were performed from July 2015 through June 2016 . To evaluate the recovery dynamics, the following indicators were measured:

\section{Vegetation}

We obtained the diameter at breast height $(\mathrm{DBH})$ of all living woody individuals (trees, shrubs, and subshrubs) having height $\geq 1.30 \mathrm{~m}$ aboveground, all of which were identified and marked with aluminum 


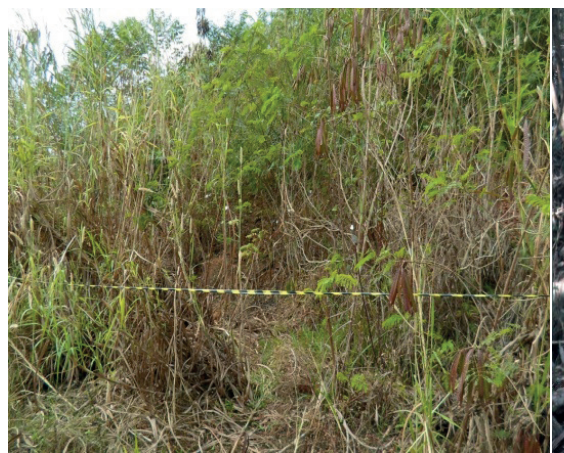

a

FIGURE I Área I (a), Área II (b) and NFF (c).

plates. Whenever possible, species were identified in situ; otherwise, vegetative and/or reproductive plant parts were collected for identification with the aid of specialized literature and consultation to herbarium collections. Family-level classification followed Angiosperm Phylogeny Group III (APG III, 2009; Souza; Lorenzi, 2008) and species names and synonyms were checked on Flora do Brasil 2020 (Brasil, 2016). Floristic diversity was estimated by Shannon-Wiener's diversity index (H') (Magurran, 1988). The individuals density, basal area and mean diameter of each environment were also obtained.

\section{Substrate and soil quality indicators}

To estimate soil/substrate cover by grasses, herbs, regenerating species, and litterfall on the substrates of mine waste dumps and on the soil of the NFF, we used a reticulate square of $0.5 \times 0.5 \mathrm{~m}$ subdivided in 4 quadrants of $0.25 \times 0.25 \mathrm{~m}$ randomly established five times within each plot, in order to obtain the mean cover (in percentage) of each indicator within the study plots $(0 \%, 25 \%, 50 \%$, $75 \%, 100 \%$ ) and the litterfall thickness (in cm).

Substrate penetration resistance is one of the physical properties of soil that are directly related to plant growth and development. In each plot, five readings were randomly taken using a Solotest soil penetrometer. Penetration resistance ( $\mathrm{qc}$ in $\mathrm{kgf} \mathrm{cm}^{-2}$ ) was obtained by dividing the maximum penetration force (in $\mathrm{kgf}$ ) by the cone base area $\left(6,33 \mathrm{~cm}^{2}\right)$.

Substrate and soil moisture content was determined using an Aquaterr sensor (Aquaterr MT300 - capacitive Sensor) in five random points within each plot at a mean depth of $5 \mathrm{~cm}$.

Light intensity was measured at nine random sites using a digital lux meter positioned at I m aboveground, between 10:00 AM and 12:00 PM. Nine measurements were made at random points. We also measured absolute light intensity, under open sky, with one repetition per treatment. Relative Light Index (RLI) was obtained by dividing the arithmetic mean of light intensity at each treatment by the light intensity under open sky and then multiplying it by 100 . In this way, it was possible to infer about the percentage of light that crosses the canopy of the vegetation in each site, and thus correlate with its density.

For particle-size classification of substrates/ soils, we collected samples composed of 12 substrate subsamples obtained at between 0 and $20 \mathrm{~cm}$ depth, and used the ABNT (NBR 7I8I/84) particle-size distribution scale. Samples were subjected to sieving and solid sedimentation in liquid medium by the pipette method (Camargo et al., 2009). For the particle-size distribution tests, we used sieves with meshes of $19.0 \mathrm{~mm}, 9.5 \mathrm{~mm}$, $4.75 \mathrm{~mm}, 2.36 \mathrm{~mm}, \mathrm{I} .18 \mathrm{~mm}, 600 \mu \mathrm{m}, 300 \mu \mathrm{m}, 2 \mathrm{I} 2 \mu \mathrm{m}$, and pan.

Substrates from Areas I and II and soil from the NFF were chemically evaluated by means of $\mathrm{pH}$ analysis in both water and $\mathrm{KCl}$, available $\mathrm{P}$ contents, concentration of bases $\left(\mathrm{Ca}^{2+}, \mathrm{Mg}^{2+}, \mathrm{K}^{+}, \mathrm{Na}^{+}\right)$, potential acidity $(\mathrm{Al}+$ $\mathrm{H}), \Delta \mathrm{pH}$, cation exchange capacity (CEC at $\mathrm{pH} 7)$, base saturation $(\mathrm{V})$, and organic matter content, according to the methods reported by Embrapa (1997). From each environment, we collected samples composed of 12 substrate subsamples obtained at between 0 and $20 \mathrm{~cm}$ depth. Both granulometry and chemical analysis were performed at the Laboratory of Waters and Soils of the Department of Environmental Engineering of the São Paulo State University “Julio de Mesquita Filho”. It is worth noting that none of the study areas was subjected to either liming or fertilizing.

\section{Data Analysis}

Results on Shannon-Wiener's diversity index in the environments were compared by Hutcheson $t$ test. Results of the evaluated attributes were subjected to ANOVA, and whenever the test was significant, Tukey's means test was then performed to indicate the differences among areas. 


\section{RESULTS}

In order to facilitate understanding of the relationships between vegetation, plant cover, and soil physical and chemical attributes, field data is displayed a single table (Table I). In all study areas, we surveyed a total 1622 individuals, distributed among 63 species and 38 families. Fabaceae was represented by nine species, encompassing $53.7 \%$ of all sampled individuals. The two most representative species at Area I were Leucaena leucocephala, with 179 individuals, and Trema micranta, with 59. At Area II, L. leucocephala was the species with highest occurrence (576 individuals), followed by Piper dilatatum (24). In the NFF, the species with highest occurrence were Piper amalago (143) and Nectandra megapotamica (I26). Shannon-Wiener's diversity index $\left(H^{\prime}\right)$ values differed between the mine waste dumps and the NFF; however, we noticed that the H' of Area I was higher than that of Area II, despite the fact that the latter is the oldest one.

Area II and the NFF did not differ significantly in mean diameter, yet they showed significantly higher values than the ones of Area I. This greater circumference of the trees of Area II may be related to their greater age, and in Area I, individuals may not yet have reached the established inclusion limit $(\mathrm{h} \geq 1.30 \mathrm{~m})$. The highest density of individuals was observed in Area II, although its basal area did not differ statistically from Area I.

The parameter soil cover by grasses did not vary statistically among the study areas, however, it is verified the decrease of its presence as the environment matures. The highest percentage of soil cover by herbaceous vegetation was found at Area I (53.08\%); in Area II and in the NFF, the values found were $19.08 \%$ and $16.36 \%$ respectively, with no significant difference between them. Soil coverage with regenerants was approximately null in Area I and increasing in Area II for NFF. For soil cover by litterfall, there was a statistical difference between the environments, with Area I increase (43.2\%) for NFF (100\%). We observed the development of thickness of the litterfall layer from $0.40 \mathrm{~cm}$ at Area I to $2.22 \mathrm{~cm}$ in Area II, the latter showing a value that is close to the one of the RS $(2.60 \mathrm{~cm})$.

The highest mechanical penetration resistance was found at Area I, while Area II showed a similar value to NFF. The increase in plant cover contributed to increasing soil humidity content. In the mine waste dumps, the increased number of plant individuals favored shading conditions $(<\mathbb{R L})$ and increased soil moisture from Area I to Area II, the latter being close to the soil
TABLE I Attributes evaluated in the three sampled areas in calcary mining.

\begin{tabular}{|c|c|c|c|c|}
\hline Features & Parameters & Area I & Area II & NFF \\
\hline \multirow{7}{*}{ Vegetation } & Individuals & 309 & 700 & 613 \\
\hline & Species & 11 & 18 & 34 \\
\hline & Families & 6 & 18 & 22 \\
\hline & $\begin{array}{c}\text { Shannon-Wiener } \\
\left(\mathrm{H}^{\prime}\right)\end{array}$ & $1.409 \mathrm{a}$ & $0.891 \mathrm{a}$ & $2.570 \mathrm{~b}$ \\
\hline & $\begin{array}{l}\text { Density } \\
\text { (ind } \cdot \mathrm{ha}^{-1} \text { ) }\end{array}$ & $2575.0 \mathrm{a}$ & $5833.3 \mathrm{~b}$ & $5108.3 c$ \\
\hline & $\begin{array}{l}\text { Basal area } \\
\left(\mathrm{m}^{3} \cdot \mathrm{ha}^{-1}\right)\end{array}$ & $0.001 \mathrm{a}$ & $0.008 \mathrm{a}$ & $0.017 \mathrm{~b}$ \\
\hline & $\begin{array}{c}\text { Mean diameter } \\
(\mathrm{cm})\end{array}$ & $0.736 \mathrm{a}$ & I. 102 b & I. $173 \mathrm{~b}$ \\
\hline \multirow{5}{*}{$\begin{array}{l}\text { Cover } \\
\text { features }\end{array}$} & $\begin{array}{l}\text { Herbaceous species } \\
(\%)\end{array}$ & $53.1 \mathrm{a}$ & $19.1 \mathrm{~b}$ & $16.4 \mathrm{~b}$ \\
\hline & $\begin{array}{c}\text { Grass species } \\
(\%)\end{array}$ & $11.2 \mathrm{a}$ & $4.7 \mathrm{a}$ & $3.9 \mathrm{a}$ \\
\hline & $\begin{array}{l}\text { Regenerating species } \\
(\%)\end{array}$ & $0.2 \mathrm{a}$ & $11.3 \mathrm{~b}$ & $40.4 c$ \\
\hline & $\begin{array}{l}\text { Litterfall } \\
\quad(\%)\end{array}$ & $43.2 \mathrm{a}$ & $76.7 b$ & $100.0 c$ \\
\hline & $\begin{array}{l}\text { Litterfall layer } \\
\quad(\mathrm{cm})\end{array}$ & $0.4 \mathrm{a}$ & $2.2 \mathrm{~b}$ & $2.6 \mathrm{~b}$ \\
\hline \multirow{3}{*}{$\begin{array}{l}\text { Physical } \\
\text { features }\end{array}$} & $\begin{array}{c}\text { Mechanical } \\
\text { Penetration Resistance } \\
\text { (MPa) }\end{array}$ & $3.0 \mathrm{a}$ & $0.5 \mathrm{~b}$ & $0.2 \mathrm{~b}$ \\
\hline & $\begin{array}{l}\text { Soil Moisture } \\
(\%)\end{array}$ & $16.3 \mathrm{a}$ & $52.9 \mathrm{~b}$ & $86.4 \mathrm{c}$ \\
\hline & $\begin{array}{l}\text { Relative Light Index } \\
\text { (RLI, \%) }\end{array}$ & $28.3 \mathrm{a}$ & $3.4 \mathrm{~b}$ & $4.8 \mathrm{~b}$ \\
\hline \multirow{5}{*}{$\begin{array}{l}\text { Particle-size } \\
\text { distribution } \\
\text { analysis }\end{array}$} & $\begin{array}{l}\text { Coarse sand } \\
(\%)\end{array}$ & 10.8 & 22.7 & 12.4 \\
\hline & $\begin{array}{l}\text { Fine sand } \\
(\%)\end{array}$ & 13.5 & 25 & 11.9 \\
\hline & $\begin{array}{l}\text { Silt } \\
(\%)\end{array}$ & 58.8 & 32.5 & 38.3 \\
\hline & $\begin{array}{l}\text { Clay } \\
(\%)\end{array}$ & 16.9 & 19.8 & 37.4 \\
\hline & $\begin{array}{c}\text { Textural class } \\
(\%)\end{array}$ & Silt loam & Loam & $\begin{array}{c}\text { Silty clay } \\
\text { loam }\end{array}$ \\
\hline \multirow{11}{*}{$\begin{array}{l}\text { Chemical } \\
\text { features }\end{array}$} & $\begin{array}{c}\mathrm{pH} \\
\left(\mathrm{CaCl}_{2}\right)\end{array}$ & 7.4 & 7.5 & 6.6 \\
\hline & $\underset{\left(\mathrm{g} \cdot \mathrm{dm}^{-3}\right)}{\mathrm{MM}^{2}}$ & 7 & 23 & 86 \\
\hline & $\begin{array}{c}\mathrm{P} \\
\left(\mathrm{mg} \mathrm{dm}^{-3}\right)\end{array}$ & 58 & 67 & 5 \\
\hline & $\begin{array}{c}\mathrm{K} \\
\left(\mathrm{mmole} \cdot \mathrm{dm}^{-3}\right)\end{array}$ & 1.4 & 2.8 & 3.1 \\
\hline & $\begin{array}{c}\mathrm{Ca} \\
\left(\mathrm{mmole} \cdot \mathrm{dm}^{-3}\right)\end{array}$ & 106 & 110 & 146 \\
\hline & $\begin{array}{c}\mathrm{Mg} \\
\left(\mathrm{mmole} \cdot \mathrm{dm}^{-3}\right)\end{array}$ & 22 & 25 & 65 \\
\hline & $\begin{array}{c}\mathrm{Al} \\
\left(\mathrm{mmole} \cdot \mathrm{dm}^{-3}\right)\end{array}$ & 0 & 0 & 0 \\
\hline & $\begin{array}{c}\mathrm{H}+\mathrm{Al} \\
\left(\mathrm{mmole} \cdot \mathrm{dm}^{-3}\right)\end{array}$ & 10 & 10 & 12 \\
\hline & $\begin{array}{c}\text { SB } \\
\left(\mathrm{mmole} \cdot \mathrm{dm}^{-3}\right)\end{array}$ & 129 & 138 & 214 \\
\hline & $\begin{array}{c}\text { CEC } \\
\left(\mathrm{mmole} \cdot \mathrm{dm}^{-3}\right)\end{array}$ & 139 & 148 & 226 \\
\hline & $\begin{array}{l}\mathrm{V} \\
(\%)\end{array}$ & 93 & 93 & 95 \\
\hline
\end{tabular}

OM: organic matter content; P: phosphorous; K: potassium; Ca: calcium; Al: aluminum; Mg: magnesium; CEC: cation exchange capacity; $\mathrm{V}$ : percentage of base saturation; SB: sum of bases; $\mathrm{H}+\mathrm{Al}$ : potential acidity. Means followed by the same letter in a row do not differ significantly by Tukey's test $(p<0.05)$. Source: own elaboration; NFF: Nature Forest Fragmention 
moisture content of NFF, showing no statistical difference between them.

Particle-size distribution analysis revealed that substrates and soils have a loamy texture with silt contents ranging from $32.5 \%$ to $58.8 \%$, being that the soil of Area II is similar to NFF. Regarding the percentage of sand, silt, and clay, we observed significant differences among the studied treatments: In the mine waste dumps, we found a higher proportion of silt, especially at Area I. A high percentage of coarse and fine sand was observed in Area II.

The $\mathrm{pH}$ values ranged from 6.6 to 7.5 , i.e., all studied substrates were alkaline, even the NFF soil. The presence of the main mineral, i.e. limestone, in the substrates led to an increase in substrate $\mathrm{pH}$, which rendered chemical variables to yield values close to the ones of the NFF. Such factor positively influenced the nutritional status of vegetation from the mine waste dumps. Particularly in terms of the mean contents of calcium ( $\mathrm{Ca})$, potassium $(\mathrm{K})$, magnesium $(\mathrm{Mg})$, and sum of bases (SB), which increased with the development of the mine waste dumps, with the highest values observed for NFF. $P$ was higher in the mine waste dumps than in the NFF soil. For SB, due to the high calcium content, the cation exchange capacity (CEC) was also considered high. In all environments, the aluminum content was null, potential acidity was low and base saturation showed values higher than $50 \%$. The organic matter (OM) content was low in substrates from the mine waste dumps, however, we observed increasing OM values from the youngest to the oldest waste dump.

\section{DISCUSSION}

The characterization of vegetation from the studied mine waste dumps indicates an advance in their natural regeneration over time in terms of individuals, species, families, basal area, and mean diameter. Regarding H', as the $\mathrm{DBH}$ measuring criterion for the vegetation was to sample all woody individuals having height $\geq 1.30 \mathrm{~m}$ aboveground, a large number of shrubs were sampled, which may have increased the value of this variable at Area I.

The Fabaceae was particularly well represented on the mine waste dumps. According to Bonini and Alves (20II), Fabaceae species are considered essential for the successful recovery of degraded lands due to their rusticity and to their high capacity for nitrogen fixation and incorporation of organic matter into the soil. Such incorporation is known to stimulate several chemical and biological processes that increase soil fertility. Furthermore, species from that family have a deep and ramified root system. For instance, studies have shown that vegetation roots, be they alive or dead, play a role in channeling and directing stemflow water through the soil, thus evidencing the occurrence of a hydrological response to rainfall events (Schwärzel et al., 20I2; Ellison et al., 2017). Fabaceae species also have high ecological plasticity, which enables them to adapt to different environments under several adverse situations.

The species with highest occurrence on the mine waste dumps was Leucaena leucocephala (Fabaceae). The presence of this species is widely discussed in the literature. The species is frequently considered aggressive, inhibitor, invasive, or ruderal (Costa; Durigan, 20 I 0; Fonseca; Jacob, 20 I I; Prach; Walker, 20 I I; Kebede, 2016). According to Lowe et al. (2000), L. leucocephala was included in the International Union for Conservation of Nature - IUCN list of the 100 world's worst invasive alien species. However, Resende and Kondo (200I) and Araújo Filho and Sousa (2006) reported that the species has a promising potential for regenerating plant cover and rehabilitating degraded lands. Santilli and Durigan (20l4) observed that even in a plant community undergoing restoration in which $94 \%$ of the planted trees ( $86 \%$ of species) were exotic, at 8 years after planting only $3 \%$ of the regenerating plants belonged to the category of exotic species, thus indicating a tendency for increase in the floristic similarity with a reference natural ecosystem over time.

When studying the arboreal species in a forest restoration project at a bauxite mining facility, Silva et al. (2016) observed that $L$. leucocephala was one of the seven exotic species used. The authors emphasize that, although the use of exotic species must be avoided, under certain circumstances, like when soils are exposed and subjected to erosion, such species have been recommended by researchers as they promote a rapid increase in cover and an improvement in soil fertility, which are particularly important in sites impacted by mining activity. Such a situation corroborates the one we observed on the studied mine waste dumps.

Overall, the presence of vegetation contributed to improving not only the cover-related features of substrates from the mine waste dumps but also their physical and chemical qualities.

Comparing soil cover among the three environments (Area I, Area II, and NFF), we observed that Area $\mathrm{I}$ is at an early stage of regeneration, with a lower presence of herbs, higher cover by grasses, and lower amount of litterfall. This is in accordance with the physical characteristics of the substrate in that area, as in 
that environment we also observed higher penetration resistance, lower soil humidity, and higher relative light index. We noticed that with the advance of natural regeneration at Area II, the variables related to soil cover and soil physical and chemical features frequently resembled the ones of the NFF.

The observed difference in soil cover by litterfall among the studied mine waste dumps can be related to the density of individuals, basal area and tree size. The highest values of those variables were observed at Area II, which might indicate that such area is at a more advanced stage of regeneration. Litterfall propitiates adequate conditions for species establishment and perpetuation, as it provides soil with cover and protection, which inhibits weed competition and enables the retention of humidity and of a high amount of nutrients in the soil.

The presence of vegetation contributes to the occurrence of lower relative light intensities within the canopy, which thus leads to not only lower thermal amplitudes and reduced water evaporation from the system, but also to a consequent higher soil humidity. The roots of canopy-forming trees also contribute to water infiltration in the soil. According to Lorenzon et al. (20I5), the forest itself contributes to the occurrence of water infiltration in the soil, since the forest cover intercepts rainwater, decreases its velocity and maintains soil humidity. Another important factor regarding the presence of vegetation concerns rainfall interception by the canopy. The more advanced is the successional stage at which a forest is, the higher is rainfall interception by the canopy, as observed by Freitas et al. (2016) in the evaluation of liquid precipitation and rainfall interception in a Seasonal Semideciduous Forest fragment at early and advanced stages of regeneration in Viçosa municipality, Minas Gerais state, southeastern Brazil.

Regarding the substrate and soil physical attributes, we observed that the mechanical penetration resistance (MPR), humidity and RLI have been improving over time. Excessive MPR values may influence root growth in both length and diameter, thus directly affecting shoot growth and development (Letey, 1985). According to Grant and Lanfond (1993), values in the range of I.5 to 3.0 MPa are restrictive to root growth. Penetration of roots of forest species is usually hampered in soils with resistance values from the 2.5 to 3.0 MPa range (Greacen; Sands, 1980). Compaction represents a threat to soil recovery, as it hampers plant growth and soil functioning (Zipper et al., 20I3). In mining sites, soil condition can get so severely affected that native vegetation hardly develops, thus leading to a situation that demands the use of aggressive exotic species that provide a good degree of soil cover (Acton et al., 20I I). The MPR value of Area I approached the one observed by Portugal et al. (2010), while the ones of Area II and NFF approached those reported by lori et al. (20I2) and Cardoso et al. (20II).

Grain-size distribution analysis enabled us to classify the substrates and soil as loamy. According to Letey (1985), loamy soils usually have an intermediate density, good aggregation, good infiltration rate, and no impediment to drainage. However, in both mine waste dumps there was a predominance of aggregates with grain size greater than $250 \mathrm{~mm}$, classified as boulders, which may represent an impeditive factor to the survival and growth of some plant species. Nevertheless, $L$. leucocephala was efficient in colonizing the mine waste dumps. It is also worth noting that there was a higher percentage of coarse and fine sand at Area II than in the other areas. This fact may be related to the flocculation of the silt and clay fractions and to their subsequent clustering into small flakes, which indicates the effect of organic matter in promoting dispersion and flocculation by the cementing effect. According to Prado and Centurion (200I), organic matter content affects the aggregation of soil particles as well as their degree of flocculation.

The presence of the main mineral of the studied mining site, i.e. calcary, led to an increase in substrate $\mathrm{pH}$. This fact denotes a considerable increase in the nutritional status of such substrate, which favored spontaneous development of vegetation on the mine waste dumps according to the soil properties, especially $\mathrm{pH}$ and CEC (Jirová et al., 2012). Calcary not only amends acidity in the substrates but also supplies them with calcium and magnesium, promoting an increase in CEC and in the availability of $P, N$, and other minerals.

Besides high calcium contents, we also found high amounts of $P$ in the mine waste dumps, which might be related to the presence of $L$. leucocephala. According to Kebebe (2016), this species might contribute with $P$ availability in the soil. Several legumes like L. leucocephala establish a double symbiosis with nitrogen fixing bacteria and vesicular-arbuscular mycorrhizae (VAM) (Mahmood et al., 2004). VAM are advantageous because they increase absorption of nutrients immobilized in the soil, especially phosphorous (ManjunatH et al., 1984). The advantages of inoculating saplings of $L$. leucocephala with mycorrhizae are the development of more roots and the increase in $\mathrm{P}$ absorption, which in turn increases the survival rates of saplings in the field and ultimately makes the species a promising alternative for reforesting and recovering degraded lands (Koffa; Cruz, 1995). 
In a degraded site in Puerto Rico, Warren and Zou (2002) evaluated the macrofauna and nutrients in the soil from plantations of $L$. leucocephala, Casuarina equisetifolia and Eucalyptus robusta, finding higher concentrations of $\mathrm{N}$, $P$, and $\mathrm{K}$ in the plantations of $L$. leucocephala than in the ones of the other species. Kang et al. (1990) observed that soils with $L$. leucocephala had higher organic matter content, higher fertility, lower thermal fluctuation, and higher humidity than soils without the presence of the species. Kebebe (2016) discusses the roles L. leucocephala plays on improving the physicochemical properties of soil, increasing soil fertility and controlling soil erosion, as well as the association between the species and soil fauna. Kang and Mulongoy (1992) reported that crop yield could be sustained at reasonable levels for several years by using $L$. leucocephala without the use of inorganic fertilizers.

Imogie et al. (2008) studied the long-term effect of $L$. leucocephala on the physicochemical properties of soil in the production of palm oil, and discovered that the soil contents of organic matter, $\mathrm{pH}$, and nutrients such as total $\mathrm{N}, \mathrm{P}, \mathrm{K}, \mathrm{Mg}$, and $\mathrm{Ca}$ were significantly higher in the sites with $L$. leucocephala than in the control. The authors also concluded that the increased amounts of nutrients in the soil was also attributed to the fact that $L$. leucocephala fixates nitrogen and contributes significantly to organic matter deposition.

The loss of organic matter is the most serious consequence of mining activity, as it not only damages soil structure but also renders insufficient the biological activity, water availability and plant nutrient supply therein. Incorporation of organic matter from the litterfall deposited due to fallout of leaves and branches from vegetation at a more advanced stage of regeneration seems to be the nutrient source that sustains vegetation on the mine waste dumps, as observed by the increased $\mathrm{SB}, \mathrm{CEC}$, and amounts of $\mathrm{K}, \mathrm{Ca}$, and $\mathrm{Mg}$ in the substrates with increasing age of the waste dumps, approaching the values observed at the RS. The same pattern was observed by Pinto et al. (2009) when comparing soil fertility between an early-stage forest and a mature one. The authors observed a great difference in soil fertility between the two forest fragments and highlighted the importance of knowing the edaphic features of soils from the early and mature forest fragments, since such features revealed the influence of soil quality on the succession process, and thus may accelerate this process in more fertile environments, reaching the stages of equilibrium and higher sustainability more rapidly. Parrota et al. (1997) conducted a study on a bauxite mining facility in the Amazon and concluded that organic matter was responsible for the successful revegetation of the area.
Due to the high calcium contents, the SB and CEC were also high, as the aluminum content was null and potential acidity was low. As for base saturation (V), all analyzed areas showed values higher than $50 \%$, which characterizes soils that have nutrient concentrations at levels considered optimal for plant growth.

\section{CONCLUSION}

From the results obtained with the adopted method, we were able to evaluate the physical and chemical conditions of the substrates during the recovery of mine waste dumps of different ages undergoing natural regeneration and correlate such conditions with a forest environment at a more advanced successional stage. Thereby, the Fabaceae predominated on the waste dumps, especially Leucaena leucocephala, which, despite being an exotic species, is relevant for the current recovery stage of the substrates. As a final remark, we point out that the advance of natural regeneration led, in time, to an improvement of the edaphic quality of substrates.

\section{REFERENCES}

ACTON, P.M.; FOX, J.F.; CAMPBELL, J.E.; JONES, A.L.; ROWE, H.; MARTIN, D.; BRYSON, S. Role of soil health maintaining environmental sustainability of surface coal mining. Environmental Science \& Technology, Easton, v. 45, n. 23, p. 10265-10272, $201 \mathrm{I}$.

ALMEIDA, R.O.P.O.; SÁNCHEZ, L.E. Indicadores da qualidade do substrato para monitoramento de áreas de mineração revegetadas. Floresta e Ambiente, Rio de Janeiro, v. 22, n. 2, p. 153-163, 2015.

ALVAREZ, C.A.; STAPE, J.L.; SENTELHAS, P.C.; GONÇALVES, J.L. de M.; SPAROVEK, G. Köppen's climate classification map for Brazil. Meteorologische Zeitschrift, Stuttgart, v. 22, n .6, p.7II-728, 2013.

ANGIOSPERM PHYLOGENY GROUP - APG III. An update of the Angiosperm Phylogeny Group classification for the orders and families of flowering plants: APG III. Botanical Journal of the Linnean Society, London, v. I6I, n. 2, p. 105-I2I, 2009.

ARAÚJO FILHO, J.A.; SOUSA, F.B. Avaliação de leguminosas arbóreas para recuperação de solos e repovoamento em áreas degradadas, Irauçuba-CE. Revista Brasileira de Agroecologia, Pelotas, v. 2, n. 2, p. 1698-170I, 2007.

ASSOCIAÇÃO BRASILEIRA DE NORMAS TÉCNICAS ABNT. Análise granulométrica, solos, método de ensaio, NBR 7I81/84. Rio de Janeiro: 1984. 15p.

BONINI, C.S.B.; ALVES, M.C. Recovery of soil physical properties by green manure, liming, gypsum and pasture and spontaneous native species. Revista Brasileira de Ciência do Solo, Viçosa, v. 35, n. 4, p. I397-I406, 20 II. 
BRASIL. 20I6. Flora do Brasil 2020 em construção. Jardim Botânico do Rio de Janeiro. Disponível em: <http:// floradobrasil.jbrj.gov.br/>. Acesso em: 18 Jun. 2016.

CAMARGO, O.A.; MONIZ, A.C.; JORGE, J.A.; VALADARES, J.M.A.S. Boletim Técnico No 106: Métodos de análise química, mineralógica e física de solos do Instituto Agronômico. Campinas: Instituto Agronômico de Campinas - IAC, 2009. Disponível em: <http://www.iac.br/ publicacoes/publicacoes_online/pdf/BT_106.pdf $>$. Acesso em: 12 Out. 2016

CARDOSO, E.L.; SILVA, M.L.N.; CURI, N.; FERREIRA, M.M.; FREITAS, D.A.F. Qualidade química q física do solo sob vegetação arbórea nativa e pastagens no pantanal sulMato-Grossense. Revista Brasileira de Ciência do Solo, Viçosa, v. 35, n. I, p. 613-622, 201 I.

CORRÊA, R.S.; BENTO, M.A.B. Qualidade do substrato minerado de uma área de empréstimo revegetada no Distrito Federal. Revista Brasileira de Ciencia do Solo, Viçosa, v. 34, n. 4, p. 1435-|443, 2010.

COSTA, J.N.M.N. da; DURIGAN, G. Leucaena leucocephala (Lam.) de Wit (Fabaceae): invasora ou ruderal? Revista Árvore, Viçosa, v. 34, n. 5, p. 825-833, 2010.

ELLISON, D.; MORRIS, C.E.; LOCATELLI, B.; SHEIL, D.; COHEN, J.; MURDIYARSO, D.; GUTIERREZ, V.; NOORDWIJK, M. van; CREED, I.F.; POKORNY, J.; GAVEAU, D.; SPRACKLEN, D.V.; TOBELLA, A.B.; ILSTEDT, U.; TEULING, A.j.; GEBREHIWOT, S. G.; SANDS, D.C.; MUYS, B.; VERBIST, B.; SPRINGGAY, E.; SUGANDI, Y.; SULLIVAN, C.A. Trees, forests and water: Cool insights for a hot world. Global Environmental Change, Oxford, v. 43, p. 5I-6I, 2017.

EMPRESA BRASILEIRA DE PESQUISA AGROPECUÁRIA - EMBRAPA. Serviço Nacional de Levantamento e Conservação de Solos. Manual de métodos de análise de solos. 2.ed. Rio de Janeiro, 1997, p. 212.

FONSECA, N.G.da; JACOBI, C.M. Desempenho germinativo da invasora Leucaena leucocephala (Lam.) de Wit. e comparação com Caesalpinia ferrea Mart. ex Tul. e Caesalpinia pulcherrima (L.) Sw. (Fabaceae). Acta Botanica Brasilica, Belo Horizonte, v. 25, n. I, p. I9I197, 2011 .

FREITAS, P.J.O.; DIAS, H.C.T.; SILVA, E.; TONELLO, K.C. Net precipitation in a semideciduous forest fragment in Viçosa city, MG. Revista Arvore, Viçosa, v. 40, n. 5, p. 793-80I, 2016.

GOEDERT, W.J.; CORRÊA, R.S. Usos, degradação e qualidade do solo. In: CORRÊA, R.S.; BAPTISTA, G.M.M.(Org.). Mineração e áreas degradadas no Cerrado. I.ed. Brasília, Universa, 2004. p. I59-I72.

GRANT, C.A.; LAFOND, G.P. The effects of tillage systems and crop sequences on soil bulk density and penetration resistence on a clay soil in Southern Saskatchewan. Canadian Journal of Soil Science, Ottawa, v. 73, n. 2, p. 223-232, 1993.
GREACEN, E.L.; SANDS, R. Compaction of Forest soils. A review. Gleis Osmond: Australian Journal of Soil Research, Melbourne, v. 18, n. 2, p. 163-89, 1980.

HONDA, E.A.; MENDONÇA, A.H.; DURIGAN, G. Factors afecting the stemflow of trees in the Brazilian Cerrado. Ecohydrology, v. 8, n. 7, p. |35|-|362, 2015.

IMOGIE, A.E.; UDOSEN, C.V.; UGBAH, M.M.; UTULU, S.N. Long term effect of Leucaena leucocephala on soil physicochemical properties and fresh fruit bunch (FFB) production of oil palm. African Journal of Plant Science, v. 2, n. I I, p. 129-132, 2008.

INSTITUTO BRASILEIRO DE GEOGRAFIA E ESTATÍSTICA - IBGE. Manuais Técnicos em Geociências: Manual Técnico da Vegetação Brasileira. 2.ed. Rio de Janeiro, 2012. Disponível em: <http://biblioteca.ibge.gov.br/visualizacao/ livros/liv630 I I.pdf> Acesso em: 20 Jun. 2016.

IORI, P.; DIAS JÚNIOR, M.S.; SILVA, R.B. Resistência do solo à penetração e ao cisalhamento em diversos usos do solo em áreas de preservação permanente. Bioscience Journal, Uberlândia, v. 28, n. Suppl. I, p. 185-195, 2012.

JIROVÁ, A.; KLAUDISOVÁ, A.; PRACH, K. Spontaneous restoration of target vegetation in old-fields in a central european landscape: a repeated analysis after three decades. Applied Vegetation Science, Bethesda, v. I5, n. 2, p. 245-252, 2012.

KANG, B.T.; MULONGOY, K. Nitrogen contribution of woody legumes in alley cropping systems. In: MULONOGY, K., GUEYE, M; SPENCER, D.S.C. Biological Nitrogen Fixation and sustainability of Tropical Agriculture, p. 367-375, 1992.

KANG, B.T.; REYNOLDS, L.S.; ATTAH-KRAH, A.N. Alley farming. Advantage in Agronomy, v. 43, p. 315-359, 1990.

KEBEDE, D. Role of Leucaena leucocephala ( Lam .) de Wit in Soil Management: A review. Agricultural Science Research Journal, v. 6, n. March, p. 7I-78, 2016.

KOFFA, S.N.; DELA CRUZ, R.E. Screenhouse performance of VAM-inoculated seedlings of Leucaena leucocephala (Lam'.) DeWit. In a phosphorus-deficient and aluminum sulfatetreated medium. New Forests, Dordrecht, v. 9, n. 3, p. 273-279, 1995.

LETEY, J. Relationship between soil physical properties and crop production. Advances in Soil Science, New York, v. I, p. 277-294, 1985.

LORENZON, A.S.; DIAS, H. C.T.; TONELLO, K.C. Escoamento da água da chuva pelo tronco das árvores em uma floresta estacional semidecidual. Revista Árvore, Viçosa, v. 39, n. 3, p. 423-430, 2015. 
LOWE, S.; BROWNE, M.; BOUDJELAS, S.; de POORTER, $M$. 100 of the world's worst invasive alien species: a selection from the global invasive species database. Auckland, New Zealand: The Invasive Species Specialist Group/Species Survival Commission/World Conservation Union IUCN, 2000. Disponível em: <http://www.issg. org/pdf/publications/worst_100/english_100_worst.pdf $>$. Acesso em: 13 Out. 2016.

MAGURRAN, A.E. 1988. Ecological Diversity and its measurement. New Jersey: Princeton University Press, 179p.

MAHMOOD, A.; IQBAL, R.; QADRI, R.; NAZ, S. Some observations on mycorrhizae of Leucaena leucocephala (Lam.) de wit. Pakistan Journal of Botany, Karachi, v. 36, n. 3, p. 659-662, 2004.

MANJUNATH, A.; BAGYARAJ, D.J.; GOPLA, H.S. Dual inoculation with VA mycorrhiza and Rhizobium is beneficial to Leucaena. Plant and Soil, Crawley, v. 78, n. 3, p. 455448, 1984

PARROTA, J.A.; KNOWLES, O.H.; WUNDERLEJR JÚNIOR, J.M. Development of floristic diversity in 10-yearold restoration Forest on a bauxite mined site in Amazônia. Forest Ecology and Management, Berkeley, v. 99, p. 21-42, 1997.

PINTO, S.I.C.; MARTINS, S.V.; BARROS, N.F. de; DIAS, H.C.T. Ciclagem de nutrientes em dois trechos de Floresta Estacional Semidecidual na Reserva Florestal Mata do Paraíso em Viçosa, MG, Brasil. Revista Árvore, Viçosa, v. 33, n. 4, p. 653-663, 2009.

PORTUGAL, A.F.; COSTA, O.D.V.; COSTA, L.M. Propriedades físicas e químicas do solo em áreas com sistemas produtivos e mata na região da zona da mata mineira. Revista Brasileira de Ciência do Solo, Viçosa, v. 34, n. 2, p. 575$585,2010$.

PRACH, K.; WALKER, L.R. Four opportunities for studies of ecological succession. Trends in Ecology and Evolution, London, v. 26, n. 3, p. II9-23, 201 I.
PRADO, R.M.; CENTURION,J.F. Alterações da cor e no grau de floculação de um Latossolo Vermelho-Escuro sob cultivo de cana-de-açúcar. Pesquisa Agropecuária Brasileira, Brasília, v. 36, n. I, p.197-203, jan. 2001.

RESENDE, A.V.; KONDO, M.K. Leguminosas e recuperação de áreas degradadas. Informe Agropecuário, Belo Horizonte, v. 22, n. 210 , p. 46-56, 2001.

SANTILLI C., DURIGAN G. Do alien species dominate plant communities undergoing restoration? A case study in the Brazilian savanna. Scientia Forestalis, Piracicaba, v. 42, n. I03, p. 37I-382, 2014.

SCHWÄRZEL, K.; EBERMANN, S.; SCHALLING, N. Evidence of doublefunneling effect of beech trees by visualization of flow pathways using dye tracer. Journal of Hydrology, Amsterdam, v. 470-47I, p. I84-192, 2012.

SILVA, K. de A.; MARTINS, S.V.; MIRANDA NETO, A.; DEMOLINARI, R. de A.; LOPES, A. T. Restauração florestal de uma mina de bauxita: Avaliação do desenvolvimento das espécies arbóreas plantadas. Floresta e Ambiente, Seropédica, v. 23, n. 3, p. 309-319, 2016.

SOUZA, V.C.; LORENZI, H. Botânica sistemática: guia ilustrado para identificação das famílias de fanerógamas nativas e exóticas no Brasil, baseado em APG II. 2. ed., Nova Odessa: Instituto Plantarum, 2008, p. 4985-4992.

WARREN, M.W.; ZOU, X. Soil macrofauna and litter nutrients in three tropical tree plantations on a disturbed site in Puerto Rico. Forest Ecology and Management, Amsterdam, v. I70, p. |6I-I7|, 2002.

ZIPPER, C.E.; BURGER, J.A.; BARTON, C.D.; SKOUSEN, J.G. Rebuilding Soils on Mined Land for Native Forests in Appalachia. Soil Science Society of America Journal, Madison, v. 77, n. 2, p. 337-349, 2013. 